\title{
Economic inequality, income, and their effects on electoral and civil society participation in authoritarian regimes
}

\author{
Lars Pelke
}

Received: 14 January 2020 / Revised: 7 October 2020 / Accepted: 23 October 2020 / Published online: 19 November 2020

(C) The Author(s) 2020

\begin{abstract}
What effect does economic inequality in authoritarian regimes have upon the political participation of its citizens? Do individual income and repression each have a greater effect than economic inequality? Three prominent theories, namely the Conflict, Relative Power, and Resource Theories address the inequality-participation puzzle in the context of democracies. However, theoretical arguments and empirical evidence for non-democratic regimes are scarce. I argue that it individual income and the level of repression rather than economic inequality that explain political participation in autocracies. Using three-level hierarchical models that combine micro and macro level data for 65,000 individuals covering a various set of 31 authoritarian regimes and 54 country-years, this analysis demonstrates that higher levels of economic inequality hardly suppress political participation among all citizens. However, individual income has a more powerfully effect on civil society participation, while the level of repression decreases the voting likelihood more powerful than income. These findings suggest that the Resource Theory generates the greatest empirical support for autocracies.
\end{abstract}

Keywords Economic inequality · Political participation · Voting · Civil society · Authoritarian regimes · World Value Survey

Replication files and the data are available at Harvard Dataverse: https://doi.org/10.7910/DVN/ SMGOZH.

Electronic supplementary material The online version of this article (https://doi.org/10.1007/ s12286-020-00463-4) contains supplementary material, which is available to authorized users.

L. Pelke $(\bowtie)$

Institute of Political Science, University of Heidelberg, Heidelberg, Germany

E-Mail: lars.pelke@ipw.uni-heidelberg.de 


\section{Ökonomische Ungleichheit, Einkommen und ihre Effekte auf elektorale und zivilgesellschaftliche Partizipation in autoritären Regimen}

Zusammenfassung Welchen Effekt hat ökonomische Ungleichheit auf die politische Partizipation der Bürger in Wahlen und der Zivilgesellschaft? Ist der Effekt von Einkommen und Repression größer als der Effekt von ökonomischer Ungleichheit? Drei bedeutende Theorien (Konflikt Theorie, Relative Macht Theorie, und Ressourcen Theorie) beschäftigen sich mit diesen Fragen für Demokratien. Theoretische Beträge und empirische Untersuchungen für nicht-demokratische Regime sind jedoch selten. In dieser Studie argumentiere ich, dass das individuelle Einkommen und das Repressionslevel politische Partizipation in Autokratien erklärt und nicht ökonomische Ungleichheit. Mit Hilfe hierarchischer Modelle, in denen Mikro- und Makro-Daten für 65.000 Individuen aus 31 Autokratien und 54 Länderjahren gesammelt werden, zeigt die Analyse, dass ökonomische Ungleichheit kaum politische Partizipation in Autokratien vermindert. Individuelles Einkommen hat dagegen einen stärkeren Einfluss auf die Partizipation in der Zivilgesellschaft, während das Repressionsniveau die Wahrscheinlichkeit der Wahlteilnahme stärker verringert als Einkommen und Ungleichheit. Die Ergebnisse weisen darauf hin, dass die Ressourcen Theorie die größte empirische Unterstützung erfährt.

Schlüsselwörter Ökonomische Ungleichheit · Politische Partizipation · Wahlen • Zivilgesellschaft · Autokratische Regime · World Value Survey

\section{Introduction}

Recent academic debates on the relationship between economic inequality and political participation (the inequality-participation nexus) focused on democratic regimes and western countries (Filetti and Janmaat 2018; Karakoc 2013; Lancee and Van de Werfhorst 2012; Ritter and Solt 2019; Solt 2008, 2010). In contrast, this study investigates the theoretical and empirical connections among economic inequality, income, and political participation ${ }^{1}$ for non-democratic regimes with data from the World Value Survey for over 65,000 individuals covering a various set of 34 authoritarian regimes. Only few studies have examined the effect of economic inequality on political participation and individual political preferences in non-democratic regimes (cf. Haggard et al. 2013; Karakoc 2013). However, as indicated by Figure A2 in the Supplementary Online Appendix, the distribution of economic inequality in autocracies is comparable with the distribution in democracies, even though more autocracyyears cluster around a GINI of 40. Even if the distribution of economic inequality

\footnotetext{
1 In this article political participation is used in its broad sense. Political participation is here defined as activities undertaken by citizens to influence political decisions (e.g. Brady 1998; van Deth 2001, 2016). This encompasses electoral participation as well as civil society engagement. However, these two branches have different causes and consequence for authoritarian regimes. For better legibility, the distinction between both is used later in the article.
} 
is comparable, the mechanisms that drive political participation in autocracies are fundamentally different from those in democracies.

Many scholars have arrived at empirical confirmations of the Relative Power Theory, and have argued that economic inequality should have a negative effect on political participation in general, and that the negative effect should be larger for poorer individuals (Ritter and Solt 2019; Solt 2008). Other studies have found evidence that the Resource Theory explains the political participation of individuals (e.g., Alesina and La Ferrara 2000; Uslaner and Brown 2005). The Resource Theory argues that higher individual income has a positive impact on political participation, and that economic inequality has a negative or positive effect on participation. In contrast to the empirical evidence for the Relative Power and the Resource Theories, the Conflict Theory has not generated much empirical evidence for a positive effect of income inequality on political participation (e.g., Solt et al. 2016, 2017). The Conflict Theory suggests that greater economic inequality leads to incompatible views on the distribution of political power between rich and poor citizens. Karakoc found that greater economic inequality leads to lesser civil society participation by all income groups, but can also mobilize civic participation of poor individuals at high levels of inequality (Karakoc 2013, p. 214). This finding supports the predictions of both the Conflict and Resource Theories.

Theoretically, this article builds on the above mentioned theories developed for democratic contexts and tests whether the theories can be applied in authoritarian contexts. The aim of this paper is to redefine the theories for authoritarian context and to arrive at a more precise theoretical specification of the causal mechanisms between inequality and political participation under authoritarianism. This article refers to the Resource Theory and argues that the theoretical mechanisms which connect individual income and political participation are affected by the level of repression and patronage in authoritarian regimes. I use the insights of the literature on repression in authoritarian regimes (e.g., Davenport 2007; Escribà-Folch 2013; Gerschewski 2013) and argue that individual income in conjunction with repression can affect political participation in authoritarian regimes. This article argues that individual income has a more powerful effect on political participation than macrolevel inequality and the interaction between income and inequality. In contrast, it further argues that repression decreases individual participation in authoritarian politics. In contrast to the Relative Power and Conflict Theories, this article expects that economic inequality will not work as a suppressing factor on political participation in authoritarian regimes, because individual political behaviour is not an extension of economic interests in authoritarian regimes. Political participation under authoritarianism is affected by information distortion, corruption and patronage networks, as well as forced mobilization and clientelism.

Therefore, income inequality should be misperceived by individuals (Gimpelson and Treisman 2018). In sum, this article expects that individual income is the main individual factor that affect participation, because richer individuals are less prone to forced mobilization and information distortion.

To demonstrate the effect of individual income and to arrive at a nuanced empirical picture of the political consequences of economic inequality in authoritarian regimes, I test my theoretical argument using three-level hierarchical models and data from 
the World Value Survey for over 65,000 individuals nested in 54 country-years across in 34 countries.

I find evidence that inequality has a less powerful effect than individual income. The results clearly demonstrate that economic inequality has the same effect, both for poor and for rich individuals. The effect of economic inequality is insignificant and very uncertain. The results also show that individual income and education have a major impact on the political participation of citizens under non-democratic rule. In accordance with my theoretical expectations, repression in the context of elections decreases voting likelihood. The results support the Resource Theory and challenge the explanatory power of the Conflict and the Relative Power Theories for authoritarian regimes.

This study contributes to the existing literature in three ways. First, by transforming the theoretical expectations as articulated by the three theories on political participation to the context of authoritarian regimes. By developing theoretical assumptions for authoritarian regimes, this article presents empirical evidence for the inequality-participation nexus in the context of authoritarian regimes. Second, this study challenges important assumptions of the Distributive Conflict Models. By investigating the determinants of political participation in autocracies, this study contributes to the literature on authoritarian elections (cf. Knutsen et al. 2017; Levitsky and Way 2010; Schedler 2013). Third, it contributes to the research on the political behavior and trust of individuals under authoritarianism (cf. Gandhi and Ong 2019; Mauk 2020). By presenting evidence that political participation is distributed unequally based on income and education, autocracies foster political participation indirectly by facilitating economic development and providing education that may have long-term effects for the stability of those non-democracies (cf. Paglayan 2020; Acemoglu et al. 2005).

\section{Previous research on political participation and economic inequality}

A large volume of the extant literature examines the effect of economic inequality on political participation, such as voting and participation in campaigns, protests, and in civil society organizations (e.g., Filetti and Janmaat 2018; Karakoc 2013; Lancee and Van de Werfhorst 2012; Solt 2008; 2010). However, most studies have concentrated on democracies, while very few have examined political participation in non-established democracies and non-democratic regimes (Table 1). There are at least two reasons for this. First, data on political participation issues as well as economic inequality are limited for non-established democracies and non-democratic regimes. However, new surveys on individual attitudes have produced data on political participation outside the OECD (e.g. World Value Survey, International Social Survey Programme). Second, comparative research on authoritarian regimes has not focused on individual participation thus far. However, research investigating the role of individual political behavior in authoritarian regimes is emerging slowly (e.g., Blaydes 2006; Brownlee 2011; Gandhi and Ong 2019; Miller 2017).

Under democratic rule political participation is thought to influence public policy outcomes and to install an elected government. In contrast to the government- 
Table 1 Recent studies investigating the inequality-participation puzzle. Independent Variable: MacroLevel Inequality. (Source: Authors compilation of studies and findings based on a review of the literature)

\begin{tabular}{|c|c|c|}
\hline Dependent Variable & Source & $\begin{array}{l}\text { Theory } \\
\text { supported }\end{array}$ \\
\hline Voting & Solt $(2008,2010)$ & Relative \\
\hline $\begin{array}{l}\text { Political participation (in general) } \\
\text { Participation in civil society }\end{array}$ & $\begin{array}{l}\text { Filetti and Janmaat (2018); } \\
\text { Lancee and Van de Werfhorst (2012) }\end{array}$ & $\begin{array}{l}\text { Power } \\
\text { Theory }\end{array}$ \\
\hline Participation in campaigns & Ritter and Solt (2019) & \\
\hline Political interest & Solt $(2010,2008)$ & \\
\hline $\begin{array}{l}\text { Political participation } \\
\text { (voting, civil society participation) }\end{array}$ & Karakoc (2013); Krishna (2008) & $\begin{array}{l}\text { Resource } \\
\text { Theory }\end{array}$ \\
\hline $\begin{array}{l}\text { Political participation } \\
\text { (civil society participation, voting) }\end{array}$ & Karakoc (2013); Bratton (2008) & $\begin{array}{l}\text { Conflict } \\
\text { Theory }\end{array}$ \\
\hline Demand for redistribution & $\begin{array}{l}\text { Ansell and Samuels (2011); Gimpelson and } \\
\text { Treisman (2018); Lupu and Pontusson (2011) }\end{array}$ & \\
\hline
\end{tabular}

forming role in democracies, political participation in authoritarian regimes has different mainly regime-stabilizing effects. By holding regular elections, authoritarian regimes try to legitimize their rule internally and externally (e.g. Gandhi and LustOkar 2009; Magaloni 2006), and showing strengths towards potential challengers in the regime elite or on the opposition (e.g. Geddes et al. 2018, pp. 129-153). Turning to the individual incentives to participate in authoritarian regimes, we can differentiate between forced participation, self-motivated participation and clientelism. Most literature argues that people participate in authoritarian elections because they expect a material reward, such as economic transfers via vote buying or patronage (cf. Letsa 2020), or they use their participation as a signal of regime support (e.g. Greene 2009; Magaloni 2006). All three types of incentives could be influenced by the level of economic inequality, the individual income and the level of repression in authoritarian regimes.

There is some evidence that the Relative Power Theory can explain political participation of individuals under different levels of economic inequality (Ritter and Solt 2019; Solt 2008, 2010). Unfortunately, we do not know much about this relationship in authoritarian regimes. Therefore, this article reviews the Relative Power, the Resource, and the Conflict Theories in this section, and examines their significance for political participation under non-democratic rule.

\subsection{Resource theory}

The Resource Theory maintains that it is individual income and not economic inequality that operates as the main driver behind political participation. Political participation, such as voting or engaging in civil society campaigns, involves investing "time to take part, money to contribute to campaigns and other political causes, and skills to use time and money effectively" (Verba et al. 1995, p. 16). Its main argument is that with increasing income, individuals are more likely to participate in political processes. Macro-level economic inequality affects political engagement by defining the distribution of economic resources among individuals. Higher macro- 
level economic inequality results in a greater concentration of money in few hands and leads to less dependence on the time invested in working (Ritter and Solt 2019, p. 679). Overall, the Resource Theory predicts, "that greater inequality will result in more participation by the relatively affluent and less participation only among the relatively poor" (Ritter and Solt 2019, p. 679). The Resource Theory assumes that the effect of individual income should be greater than the effect of economic inequality on participation. Karakoc has shown empirical evidence for the Resource Theory for non-democratic regimes and has demonstrated that the Resource Theory explains civil society participation in post-Communist countries, by both repressing and mobilizing civil society participation (Karakoc 2013).

\subsection{Conflict theory}

The Conflict Theory argues that macro-economic inequality increases individual political participation. Based on the assumptions of the Meltzer-Richard theorem (1981), the Conflict Theory assumes that greater inequality implies that poor individuals are poor in relative comparison with rich individuals, "so redistributive policies should become more attractive to them as a means of improving their circumstances" (Solt 2008, p. 49). If the poor intend to demand redistributive policies, they are more likely to either participate in organizations that demand redistribution or to vote for parties that advocate for them and their rights. In contrast to the demands of the poor, the rich are interested maintaining the status quo, so they participate in political parties and organizations that aim to implement policies that reduce the likelihood of redistribution. The Conflict Theory predicts that at higher levels of macro-level inequality, the views of the poor and the rich will oppose each other strongly. Therefore, greater economic inequality should result in more political interest and participation, on parts of both the rich and the poor. In sum, higher economic inequality leads to more incompatible preferences which generates more conflictive politics.

A few studies on political participation under authoritarianism have suggested that the poor are more likely to participate in politics than the rich (e.g., Bratton 2008; Krishna 2008). Bratton showed that the poor are more likely to participate in community meetings and vote more frequently than the affluent in 12 African countries (Bratton 2008). However, these findings mainly support the Conflict Theory, but do not include measures of economic inequality. Haggard et al. (2013) investigated the effect of macro-level inequality on perceptions of redistribution for 41 developing countries. They found that inequality only has limited effects on demands for income redistribution, while preferences of low-income groups "vary significantly depending on occupation and place of residence" (Haggard et al. 2013, p. 113).

Recent studies have indicated that perceived inequality and not the real level of inequality constitutes the main driver for the demand for redistribution (Ansell and Samuels 2011; Gimpelson and Treisman 2018; Lupu and Pontusson 2011). Political participation should not affected by economic inequality. Rather, it should be affected by the perception of inequality by each individual. Gimpelson and Treisman found that less than one-third of the respondents in their study chose the actual country's inequality level correctly by using survey data for 40 democratic countries (2018, 
p. 32). These findings indicate that macro-level inequality cannot be a predictor of redistributive conflicts between the rich and the poor. Thus, the Conflict Theory cannot predict the likelihood of participation, when we assume that redistributive preferences are the main driver of political participation in authoritarian regimes.

\subsection{Relative power theory}

The Relative Power Theory has generated the most consistent empirical findings explaining the political participation of individuals in democracies. Solt (2008) studied 23 democracies and showed that economic inequality powerfully depresses electoral participation, and also noted that this effect is more powerful for those with lower levels of income. This confirmes the Relative Power Theory. Ritter and Solt (2019) noted in the context of US elections that "higher levels of economic inequality mean that poorer people will have less and richer people more of the resources needed not simply to participate in campaign activities, but to shape the scope of politics" (2019, p. 11). Economic inequality should normally decrease political participation, and should have a more negative effect on the participation of the poor. The theory argues that economic inequality produces political inequality. Consequently, the Relative Power Theory argues that "contexts of greater economic inequality enable richer individuals not simply to prevail more often in an actual political contest, but also to more fully reshape the political agenda to exclude whatever issues that poorer citizens would have otherwise wished to debate, and even to more completely convince these poorer citizens to abandon preferences they would have otherwise held" (Ritter and Solt 2019, p. 679). However, why should poor individuals participate in politics when there are high levels of inequality? The Relative Power Theory offers different reasons for this. As a result of the power imbalance under a state of high economic inequality, the poor have less political power than rich individuals, and are more likely to fail in their political initiatives and demands. Repeated failures lead to the political demobilization of the poor and this, in turn, leads to less political participation in elections and civil society activity. This effect should all the more pronounced in authoritarian regimes because political participation rights are either restricted or absent based on the competitiveness of those regimes, and the poor have lesser capacity to use informal channels that influence political decisions of the ruling coalition.

\section{Theoretical argument and hypotheses}

I argue that that it is not economic inequality that causes political inequality, but individual income and the effects of repression that affect the likelihood of political participation in authoritarian regimes. This section builds theoretical arguments and proposes mechanisms that connect individual income, repression, and political inequality. ${ }^{2}$ Based on the literature review above, this article tries to apply theoreti-

\footnotetext{
${ }^{2}$ I define political inequality as a participation gap between rich and poor individuals and the political consequences of this participation gap.
} 
cal assumptions of widely-used theories for democratic contexts to the authoritarian environment. In doing so, this article engages with the specific characteristics of political participation under authoritarianism. ${ }^{3}$

Contemporary authoritarian regimes hold elections regularly and enable civil society organizations to participate in authoritarian politics. Therefore, civil society participation and electoral participation are two types of restricted political participation in contemporary authoritarian regimes, even when such types of participation are not directly connected to demands for democratization. Nevertheless, research shows that authoritarian regimes with multiparty elections are more likely to democratize after elections (e.g., Knutsen et al. 2017; Wright and Escribà-Folch 2012). Therefore, elections and large-scale political mobilization in civil society can be major factors that affect the stability of authoritarian regimes (e.g., Hadenius and Teorell 2007; Knutsen et al. 2017; Morgenbesser and Pepinsky 2019). However, political participation in general does not necessarily affect the balance of power.

Political participation under authoritarianism is influenced by information distortion through controlled media environments (e.g. Chen and $\mathrm{Xu}$ 2017; Guriev and Treisman 2015), corruption and patronage networks (e.g. Chang and Golden 2010), and forced mobilization by vote buying and economic incentives for pro-regime voting (González-Ocantos et al. 2012; Nichter 2008). Individuals can express their demand for policy change through different forms of political participation and mobilization, such as participation in mass protests and voting for regime opponents.

In addition, individuals have different incentives to participate in authoritarian regimes. Individuals can be self-motivated to participate in politics in the context of dictatorship to demand for leadership or policy change. This self-motivated participation is connected to the economic reasons for voting (cf. Letsa 2020) when individuals expect a material reward, such as direct transfers via vote buying or patronage networks. In addition, political participation, in particular voting in autocracy, can be a consequence of forced participation in a compulsory voting system or by incentives via vote buying or repression. In this section, this article connects the question why people choose to participate in politics when it is clear that political participation will not bring policy change with individual characteristics and contextual factor of authoritarian regimes.

This article refers to the empirical literature and its findings, and argues that economic inequality cannot influence the likelihood of political participation in authoritarian regimes at a large scale. In the next section, it presents four related mechanisms connecting income, economic inequality, and repression with political participation in authoritarian regimes. I rely on the Conflict, Resource and Relative Power Theories and adjust the assumptions of these theories to suit the context of political participation in authoritarian regimes. This article argues that economic inequality is not the main driver of political inequality in authoritarian regimes.

\footnotetext{
3 According to Yom's (2015) distinction between a deductive template and inductive iteration of research practices and hypothesis formulation, this article uses a twofold strategy of theory and hypothesis formulation. In a process of deductive inquiry the above mentioned theories were adapted to the field of participation under autocracies, while in a later stage inductive iteration was used to further elaborate the theoretical arguments concerning vote-buying and repression in a dialog with the data presented in the article.
} 


\subsection{The role of repression and income}

First, I argue that inequality should neither increase nor decrease political participation in authoritarian regimes more than individual income, although economic inequality increases the gap in policy preferences between the poor and the rich individuals. This has at least three reasons: first, economic inequality is largely misperceived by individuals and therefore cannot be a good predictor of individual participation (Gimpelson and Treisman 2018; Haggard et al. 2013). Second, the information available on economic inequality in authoritarian regimes is confined by media restrictions and information bans. This gap intensifies the likelihood of the misperception of the real levels of economic inequality. Third, individuals do not believe that economic inequality and voting for redistributive policies translate into changes in policies outputs and outcomes. Thus, I assume that economic inequality has no effect on political participation in authoritarian regimes.

Second, as the Resource Theory has argued, with increasing income, individuals are more likely to participate in political processes. I assume that this connection holds in authoritarian regimes as well. I start with incentives for individuals to participate in political processes. Individuals can participate in elections to express satisfaction or dissatisfaction with the incumbent government by voting for the regime party or the opposition. Individuals can also express their dissatisfaction with the regime by not participating in elections. Individuals can engage with both proregime and anti-regime civil society organizations or can participate in anti-regime organizations. I also expect that non-participation has no signalling effect on the regime. Each individual evaluates the cost and benefits of voting for the opposition against the costs and benefits of voting for the incumbent party. Compulsory voting systems and informal social pressure in local communities influence the costs of nonvoting. In some authoritarian regimes, the social pressure from local communities and village chiefs to participate in elections are high, such as in China (He 2007). This individual decision-calculus is mainly influenced by both the individual income and resources of individuals, such as education and employment. In general, this article expects that the individual income and the perceptions of the costs and benefits of participation influence the likelihood of participation. In sum, I argue that the Resource Theory is powerful in explaining the political participation of individuals under authoritarianism.

Third, I assume that the level of repression around authoritarian elections and the repression of anti-regime civil society organizations influence the likelihood of individual participation in elections or engagement with the civil society organizations. Most authoritarian regimes are based on a relative small winning coalition that is dominated by richer individuals who are important for the authoritarian elite to survive. Repression should affect the poor more than the rich, who have the ability to compensate the effects of repression with individual income through corruption 
or monetary compensation for penalties. ${ }^{4}$ In addition, richer individuals are more likely to be part of patronage networks. In contrast to the Conflict Theory, the poor are less likely to participate in regimes with high levels of repression. The level of repression should influence the individual decision-making process with respect to participation. I expect that individual income and repression will interact with each other. Repression during elections and of civil society should affect the poor people more than affluent individuals.

Fourth, I expect that vote buying increases the likelihood of individuals to vote in elections in general, while among the poor it should have a greater positive effect on participation (González-Ocantos et al. 2012; Nichter 2008). Authoritarian regime parties can buy the votes of less affluent people more easily than the votes of the rich. The poor typically have a below average education and may be more likely not to understand when an attempt to buy their votes is made.

\subsection{Brief review of theoretical predictions}

This section presents a brief overview of the theories and its extensions. The Resource Theory predicts that the effect of inequality on political participation is conditional on individual income levels (line A, Figure A1, online appendix). It indicates that the effect of economic inequality is negative, but will be smaller than the effect of individual income. The product of the interaction of individual income and inequality and the effect of inequality should be smaller than the income effect. Therefore, based on these theoretical expectations, I frame the following hypothesis:

Hypothesis 1 Individual income is likely to increase political participation in authoritarian regimes.

Second, the Relative Power Theory predicts that economic inequality has a negative effect on political participation (line B, Figure A1, online appendix) and that the interaction between inequality and income has a positive effect on participation (line C, Figure A1, online appendix), indicating a more negative effect for lower incomes on political participation. It maintains that the magnitude of inequality should be greater than the product of individual income and the interaction of income and inequality. It suggests the following hypothesis:

Hypothesis 2 Economic inequality decreases political participation in autocracies in general, and the effect is stronger on those with lower levels of income.

Third, the Conflict Theory predicts that greater economic inequality results in greater political participation of individuals, irrespective of whether they are rich or poor (line B, Figure A1, online appendix). It suggests the following hypothesis:

\footnotetext{
4 Repression may not randomly distributed along individuals. Rather, it is much more likely that individual experiences of repression or vote buying cluster at the group level. Group levels can be, for example, ethnic or social class membership. However, this article does not include a fourth level of analysis to account for this assumption due to the lack of mapping instruments and the problem of model interpretation.
} 
Hypothesis 3 Economic inequality increases political participation in authoritarian regimes, independent of the individual income level.

Fourth, this article assumes that repression of civil society organizations and repression in the context of authoritarian elections would decrease the likelihood of political participation (line D, Figure A1, online appendix). My theory assumes that the decreasing effect of repression should be more pronounced for the poor (line E, Figure A1, online appendix). Thus, the following hypothesis is presented:

Hypothesis 4 Repression is likely to decrease political participation in autocracies in general, and should affect lower levels of income more strongly than higher levels of incomes.

Fifth, my theory predicts that vote buying should increase the likelihood of individual participation in authoritarian elections. However, the effect would be conditioned by individual income levels. The theory predicts the following hypothesis:

Hypothesis 5 Vote buying increases electoral participation in autocracies in general, and increases the likelihood of voting more powerfully on lower levels of incomes.

\section{Data and methods}

This study addresses the effects of economic inequality, income, and repression on the political participation of individuals by examining the relationships among them in a diverse sample of authoritarian regimes. Democratic country-years are excluded because this study focuses on political participation in non-democratic regimes. As mentioned earlier, political participation and the effects of income, repression, and inequality have features that are different from those in democracies. To differentiate between democratic and autocratic regime-years, I use the Regimes of the World distinction based on V-Dem indicators (Lührmann et al. 2018).

Drawing accurate cross-level inferences requires information on individual characteristics and contextual factors. The individual data used in this study are sourced from the World Value Survey (2016). The contextual data comes from Solt's data on economic inequality (SWIID 2020) and from the Varieties of Democracy dataset (Coppedge et al. 2020a). Information on countries and country-years included in this study is presented in Online Appendix A.

This article combines the cross-national survey data collected in different waves of the WVS with data on inequality from the SWIID (Solt 2020) and political regimes (Coppedge et al. 2020a). Two datasets are built: The electoral participation dataset includes 35,678 respondents in 28 country-year contexts in 22 multiparty authoritarian regimes from the fifth and sixth wave of the World Value Survey. The civil-society participation dataset includes 65,713 respondents in 54 country-year contexts in 34 authoritarian regimes from wave 2-6 of the World Value Survey. ${ }^{5}$ The including criteria are the following:

\footnotetext{
5 Compare Table B1-B5 in the Online Appendix.
} 
1. A respondent has information on the dependent and individual independent and control variables;

2. a country-year has information on all country-year independent and control variables. ${ }^{6}$

In contrast to Civil Society Participation dataset, the Electoral Participation dataset only includes those country-years in which the authoritarian regime is classified as a multiparty authoritarian regime. Multiparty authoritarian regimes are those regimes in which at least one real opposition party is allowed to compete in authoritarian elections. However, the political competition can be legally and/or informally highly constrained by the authoritarian incumbent party. ${ }^{7}$

\subsection{Dependent variables}

Self-censorship of political preferences and regime support in authoritarian regimes can produce a significant bias on questions regarding the citizen-regime relationship (e.g., Robinson and Tannenberg 2019; Tannenberg 2017). The potential of selfcensorship may be more problematic in more autocratic regimes (Tannenberg 2017 , p. 21). Respondents have two options in the context of high political fear: preference falsification and item non-response (cf. Mauk 2020, pp. 88-92). Preference falsification can be detected by examining interviewer evaluations of the respondents' demeanour during the interview (e.g. Mauk 2020) or by evaluating survey item on perceived survey sponsors (e.g. Tannenberg 2017).

The first way to detect preference falsification lead to the conclusion that on average $5.8 \%$ of the respondents appeared suspicious and $2.3 \%$ appeared dishonest in African autocracies, while in Asian autocracies 2.3 of the respondents seemed insincere in answering interview questions (Mauk 2020, p. 89). Mauk concluded that the falsification rates are similar to the ones in democracies. The second way to detect preference falsification introduced by Tannenberg (2017) results in the conclusion that survey items on trust in different government institutions and political preferences of respondents suffer from autocratic trust bias for political sensitive survey questions. Therefore, preference falsification is more problematic, the more potentially sensitive a question is and the more the respondent believes that the government has commissioned the survey. Unfortunately, the WVS does not ask a question on the perceived survey sponsor or on interviewer evaluations of the respondents' demeanor. In addition, Robinson and Tannenberg (2019) found that the level of self-censorship ranges from 24.5-26.5 percentage points in China and is more prevalent among the wealthy, urban, young respondents. However, these rates of self-censorship apply for highly repressive regimes, such as China, and are more

\footnotetext{
${ }^{6}$ In the Supplementary Online Appendix D5 and E6 additional robustness tests are implemented using multiple imputation for individual missing observations. Information on what country-years are excluded can be found in Supplementary B.

7 By excluding closed autocracies, such as China or Qatar, this study decreases the potential bias of selfcensorship by respondents in surveys in highly repressive environments.
} 
relevant for more sensitive questions, such as trust in the ruling party, or perception for democracy.

Item non-response is the second indicator for autocratic trust bias. "Respondents afraid of repercussions may refuse to answer to politically sensitive questions or pretend to 'don't know' or 'can't choose' an answer' (Mauk 2020, p. 90). Mauk found that there is no systematic pattern of non-response across regime types and the level of repression.

However, survey data from authoritarian regimes are the more problematic, the more politically sensitive a question is. The questions used in this study, ask whether respondents voted in the last elections. This question may be less sensitive because regimes cannot generate approval rates for the incumbent party in multiparty authoritarian regimes. Moreover, the survey items regarding the civil society participation may be also a less sensitive question because such questions ask whether someone take part in a wide spectrum of civil society organizations that can be part of the political regime infrastructure as well as the opposition. Yet, if we want to study political actions and preferences across authoritarian regimes on a global scale, we must rely on public opinion surveys. However, we should be careful in interpreting such findings regarding the potential autocratic trust bias.

\subsubsection{Electoral participation}

Data on individual voting behavior in the last elections were collected for 22 multiparty authoritarian regimes and 28 country-years from the World Value Survey. The survey examined whether respondents voted in the last national or legislative elections. However, the World Value Survey asked this question only in the last two rounds. Therefore, only authoritarian regimes after 2005 have data on this item. The average reported turnout across elections was $76 \%$. However, voting varies across countries, over time, and among individuals with different economic capacities. In Thailand, over $98 \%$ of the citizens said that they had voted ${ }^{8}$ in the last national elections in 2013, while in Morocco only $39.3 \%$ reported that they had voted in the last national elections.

\subsubsection{Civil society participation}

Data on civil society participation come from questions that ask whether respondents belonged to any of the following types of civil society organizations, such as social welfare service, cultural or educational societies, labor unions, political parties, local political organizations, human rights groups, professional organizations, youth movements, sports clubs, women's organizations, peace movements, heath organizations, and other civil society organizations. When a respondent indicated belonging to any of these groups, the civil society variable was marked as 1 , and 0

8 Thailand has a compulsory voting system. 
if the respondent indicated non-participation. ${ }^{9}$ Data for civil society participation were collected for 34 authoritarian regimes over 54 country-years. On average, individuals in Jordan in 2007 and Egypt in 2012 had the lowest levels of civil society participation. The highest civil society participation was recorded in Armenia in 1997 and in Rwanda in 2012 with over 80\% individual participation rates. ${ }^{10}$

However, my coding of civil society participation is subject to some degree of uncertainty. Some authoritarian regimes have used regime-founded civil society organizations to monitor and integrate civil society into a broader strategy of legitimation of the regime. For example, youth movements such as the Free German Youth in the German Democratic Republic or the Hitler Youth in Nazi Germany were used by the regime for co-optation and monitoring of the civil society. Contemporary authoritarian regimes also use regime-controlled civil society organizations such as the "General Confederation of Labour" which is controlled by the Communist ruling party in Vietnam. Therefore, the civil society participation variable does not offer a flawless measure of participation. Nevertheless, it provides important insights on individual participation in civil society and is the only available cross-national measure of civil society participation.

\subsection{Independent and control variables}

The main independent variables are countries' economic inequality and individual income. Unfortunately, data on economic inequality for non-western countries are scarce. The Standardized World Income Inequality Database (SWIID 8.3) provides comparative data on market income inequality and post-tax and post-transfer inequality. Solt (2020) generated a comprehensive dataset for a rich sample of countries, including several authoritarian regimes. The dataset is based on the methodological standards of the Luxembourg Income Study and provides information on uncertainty in the point-estimators for income inequality. This study uses data for both market income and post-tax inequality. ${ }^{11}$ While 0 indicates that each household receives an equal share of income, 1 indicates that a single household receives all income. The median-voter theorem argues that market inequality is relevant for individual redistribution preferences. However, this study aims to estimate the effect of inequality on political participation and not individual redistribution preferences. Therefore, I use both inequality measures to study whether market or disposable income inequality matters for the likelihood of political participation. ${ }^{12}$ The results reported in this paper are based on market inequality. Results based on post-tax inequality are reported in the Supplementary Online Appendix.

\footnotetext{
${ }^{9}$ Compare the original coding by Karakoc (2013). In additional robustness tests, I excluded membership in political parties and belonging to a party from the civil society participation variable to consider the fact that political party membership is informally or formally compulsory in some authoritarian regimes.

10 Figures B1 and B2 present descriptive evidence of the fact that individual political participation is influenced by individual income in my sample of authoritarian regimes.

11 Post-tax inequality is based on disposable household income distribution. Disposable inequality $=$ posttax/transfer inequality.

12 For a discussion on market and disposable inequality, see Schmidt-Catran (2016).
} 
The second main independent variable is individual income. The theories argue that the effect of economic inequality on the country-level depends on individual income. Therefore, the empirical models test for individual income and the crosslevel interaction between individual income and economic inequality. The income quintile of each respondent's household was used for measuring income in this study. ${ }^{13}$

At the individual level, this article controls for a series of variables that have been found to affect the political participation of individuals: gender (dummy variable), age (continuous), children (dummy variable, 1 = parents), formal education (eight categories, from no formal education to university degree), and labor status (dummy variable, $1=$ unemployed). Education foster political participation by increasing civic skills and political knowledge "that functions as the causal mechanisms triggering participation" (Persson 2015, p. 698). However, education can also work as a proxy variable for other factors, such as socialization or social status among others (Croke et al. 2016; Persson 2015). Therefore, I would assume that education is a main driver of political participation under authoritarian rule.

At the country-year level, the models include a series of contextual factors that should have a substantial effect on individual participation. However, because the country-year sample is small with around 28-54 country-years, I selected the country-year controls carefully. A recent study has shown that multilevel models with a small number of upper level-units produce unbiased estimates and confidence intervals while using frequentist maximum likelihood estimators (Elff et al. 2020). Nevertheless, the results should be interpreted with caution.

Political participation under authoritarianism is influenced by the perception of individuals on facing repression for divergent behavior. This article expects that individuals behave differently under higher and under lower levels of perceived repression.

Unfortunately, data on perception of repression are not available at the individual level. Therefore, the models uses macro-level data to measure these variables. To analyze voting likelihood, it uses the clean elections index by V-Dem to measure perceived repression in context of elections. This index measures the "absence of registration fraud, systematic irregularities, government intimidation of the opposition, vote buying, and election violence" (Coppedge et al. 2020b, p. 47) and, therefore, covers the concept of perceived repression more precisely than a variable on violence in elections. To analyze civil society participation, this article uses civil society organization repression to test the effect of repression on the likelihood of participation. The variable measures whether "the government attempt to repress civil society organizations" (Coppedge et al. 2020b, p. 182). The models also control for vote buying using an indicator on this (Coppedge et al. 2020b, p. 63). However, vote-buying measurements are notoriously uncertain due to different effects: e.g. preference falsification of respondents, indirectly measured proxies, selection bias, and non-notice of vote buying efforts (e.g. Hicken et al. 2015; Mares et al. 2017).

13 In the Online Appendix, additional robustness tests used income deciles for measuring individual income. 
Therefore, the findings based on my macro-level proxy for vote-buying should be interpreted with caution.

In addition, the models control for previous democratic experiences of authoritarian countries. Citizens who grew up under democracy or experienced democratic elections and political participation in a democratic context may be more willing to participate under an autocracy. Previous democratic experience is measured by the maximum value of the liberal democracy index (Coppedge et al. 2020b, p. 43) when a country had a democratic period according to the Regimes of the World indicator. Otherwise, it was coded as a 0 . The models also control for the social support base of authoritarian regimes. By using the Regime support groups indicators by V-Dem (Coppedge et al. 2020b, p. 132), this article controls on which social groups the authoritarian regime rely on in order to maintain power. The Relative Power Theory expects that repeated failures of political initiatives and demands lead to political demobilization of the poor. However, this expectation is dependent on the social power base of the authoritarian regime. Authoritarian regimes that largely rely on the rural and urban working class and the middle class, should have higher electoral participation as well as civil society participation rates compared to regimes that rely largely on party and business elites. ${ }^{14}$ They also control for economic prosperity (GDP per capita) on the country-year level.

All country-year variables and continuous or categorical independent variables are mean-centered by the grand mean for the sake of better interpretation of coefficients in multilevel models and faster estimation of binary dependent models. In addition, the theories predict that income inequality and individual income interact with each other.

Therefore, the models test for interaction effects between income and inequality. They also test for interaction effects between individual income and the repression variables as well as the vote buying variable.

\subsection{Empirical method}

The theoretical models that are presented in this paper need multilevel modelling to examine the effect of contextual factors on participation. Therefore, this analysis uses three-level hierarchical models: individuals ${ }_{i}$ are nested in country-years ${ }_{t}$ that are nested within countries ${ }_{j}$. The model has the following form:

$$
\text { political participation }_{\mathrm{jti}}=\beta_{0}+\beta_{1} X_{\mathrm{jti}}+\gamma_{1} Z_{j t}+\vartheta_{j}+\mu_{j t}+\epsilon_{\mathrm{jti}}
$$

The use of random slope models (Model 5-7) allows the effect of individual income to vary in terms of both magnitude and effect direction among country-years. Using separate error terms for countries $\vartheta_{j}$ and country-years $\mu_{j t}$ my models enable the inclusion of independent variables at all three-levels. However, the models do

\footnotetext{
14 The indicator regime support group is built by taking the country-year maximum of the following indicators: v2regsupgroups_9 (urban working class), v2regsupgroups_10 (urban middle class), v2regsupgroups_11 (rural working class), and v2regsupgroups_12 (rural middle class). The resulting indicator ranges from -0.226 to 0.524 .
} 
not include country-variables. Since measures for political participation take binary values, all models were estimated using logistic hierarchical models.

\section{Empirical findings}

In this section, I present the empirical results of the three-level hierarchical analysis of the impacts of inequality, income, and repression on political participation. First, I graphically present the results of the empirical models for the likelihood of voting in authoritarian regimes. Second, I show the results of my models estimating the likelihood of civil society participation.

\subsection{Voting in elections}

Fig. 1 reports the results of the main models estimating the effects of inequality, individual income, and repression on political participation in elections. The intraclass correlation coefficient of the empty model shows that $73.6 \%$ of the variance comes from between-individuals, and $26.4 \%$ comes from the country-year level. ${ }^{15}$ Model 1 is the baseline model without any independent predictors. Model 2 includes all individual-level variables. Models 3-7 add country-year predictors and estimate the effects of income inequality on the likelihood of voting. Fig. 1 shows the results of Models 2-7 as a dot-whisker plot. The dots represent the logit coefficients and the whiskers show the $95 \%$ confidence intervals (see Solt and $\mathrm{Hu} 2015$ ). For comparability, all ordinal and continuous predictors were rescaled by multiplying the unstandardized coefficients of these variables by two standard deviations. Using this standardizing technique, the rescaled coefficients were made directly comparable with those of the dichotomous predictors. The coefficients represent the expected change in the logged odds of the participation variable occurring for a change in an independent variable from one standard deviation below to one standard deviation above the mean (cf. Ritter and Solt 2019, p. 684).

Individual control variables mainly performed as expected. I found that bettereducated people are more likely to vote and that age has a positive effect on the likelihood of voting as well. Those that are unemployed are less likely to vote, while those who have children are more likely to vote than those who are childless.

The two variables of main interest in the Resource, Conflict, and Relative Power Theories, namely macro-level income inequality and individual income, do not show such consistent results with the theoretical expectations. Fig. 1 suggests that a change of one standard deviation below the mean to one standard deviation above the mean in the macro-level economic inequality results in a 0.35 decrease in the logged odd ratio of voting. ${ }^{16}$ An estimated change from a 1.3 decrease, a substantial negative effect, to a 0.61 increase, a substantial positive association, shows the uncertainty of the predicted estimate. For the effect of individual income, one can see that the coefficient is positive but very small, indicating only a weak association of individual

\footnotetext{
15 Based on the baseline model.

16 Based on Model 6.
} 


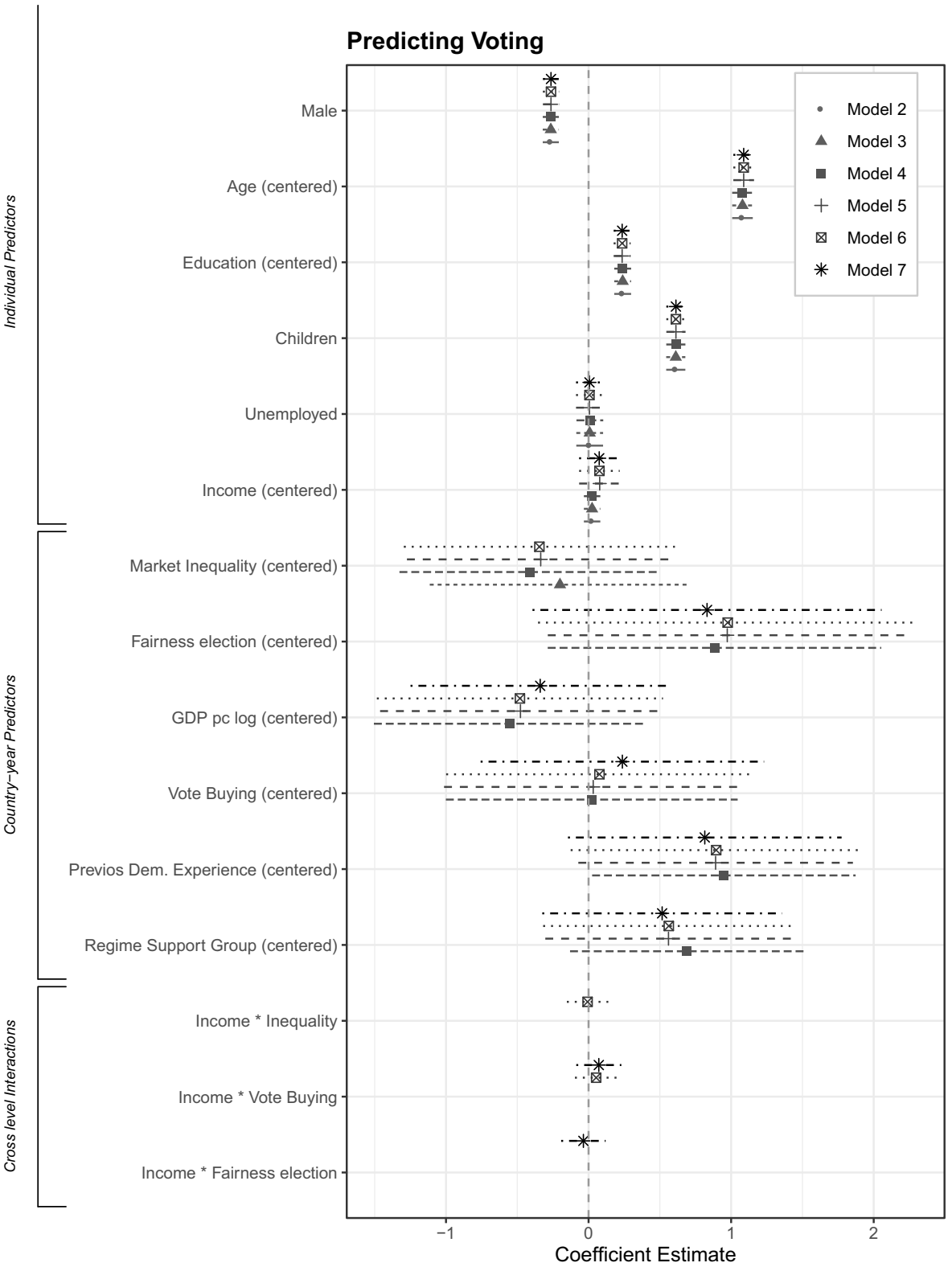

Fig. 1 Effects of Income, Inequality, and Fairness of Elections on Voting (The dots represent estimated changes in the logged odds of voting (dependent variable) occurring for a change of two standard deviations in the predictor variables. The whiskers show the $95 \%$ confidence intervals of these estimates) 


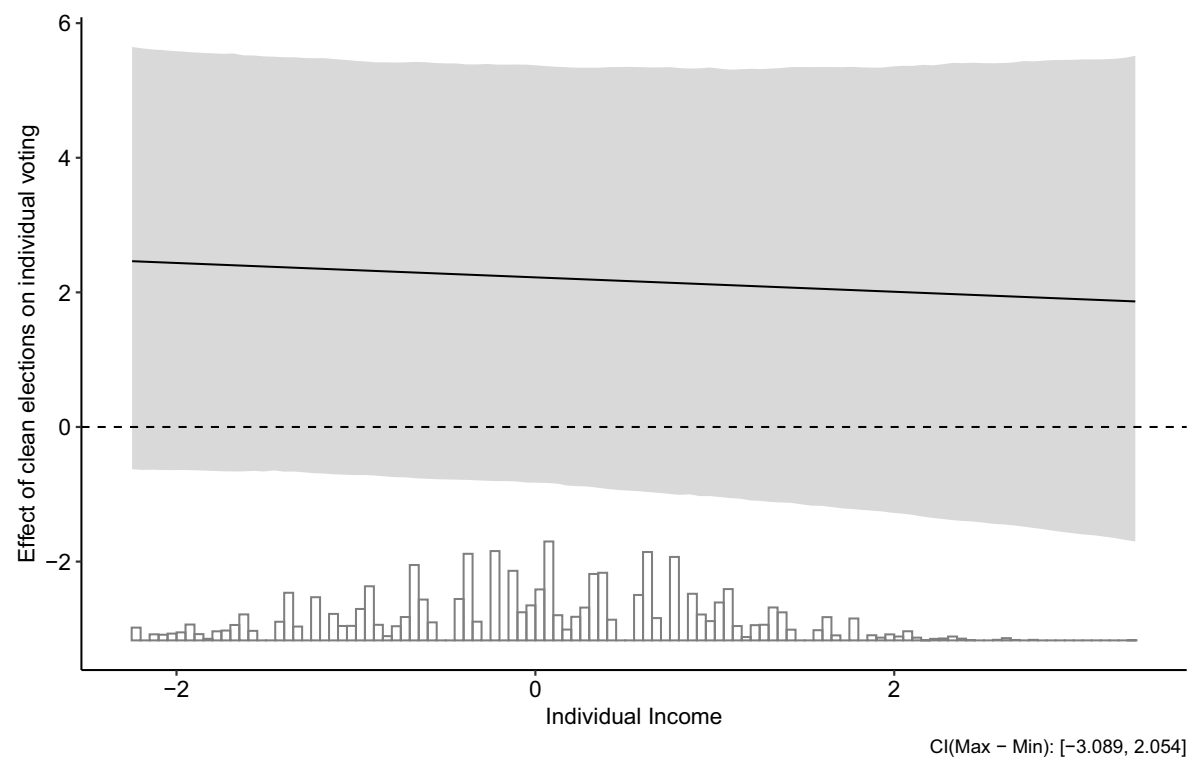

Fig. 2 Estimated Coefficients of Clean Elections by Individual Income (Based on Model 7 in Fig. 1. Conditional effects of individual income and clean elections. The lines represent the estimated change in the logged odds of the dependent. The shaded regions show adjusted $95 \%$ confidence intervals)

income with voting likelihood. Models using disposable inequality (post-tax and post-transfer) are reported in Section C1 in the Supplementary Online Appendix. The results hold irrespective of whether I use pre-tax or post-tax income inequality measures.

The Relative Power and the Conflict Theories expect the impact of interactions between macro-level inequality and individual income on individual voting, while the Resource Theory claims that macro-level inequality does not matter more than income for individual behavior. Figure A3 shows that, in contrast to the assumption under the Relative Power Theory, economic inequality does not play an important role in suppressing the likelihood of the poor voting. The expectation of the Conflict Theory does not hold: Individuals at lower income levels do not have an increased likelihood of voting under higher economic inequality.

In the next step, I test $\mathrm{H} 4$ and H5, which postulate that repression decreases and vote buying increases the voting likelihood. Both should affect the poor more than more affluent people. As Fig. 1 demonstrates, the fairness of elections has a positive effect on voting likelihood, thus indicating a negative effect of repression. I also tested the interaction effect between individual income and clean elections using the effect of clean elections over different income levels. Fig. 2 shows that the estimated coefficient of clean elections is positive across different individual income levels. It clearly indicates that the effect of clean elections on voting likelihood is not conditional on the individual income level. In contrast to the assumption under $\mathrm{H} 4$, the effect of clean elections is not affected by individual income. Fig. 1 also reveals that vote buying has no substantial positive effect on voting likelihood. The effect 


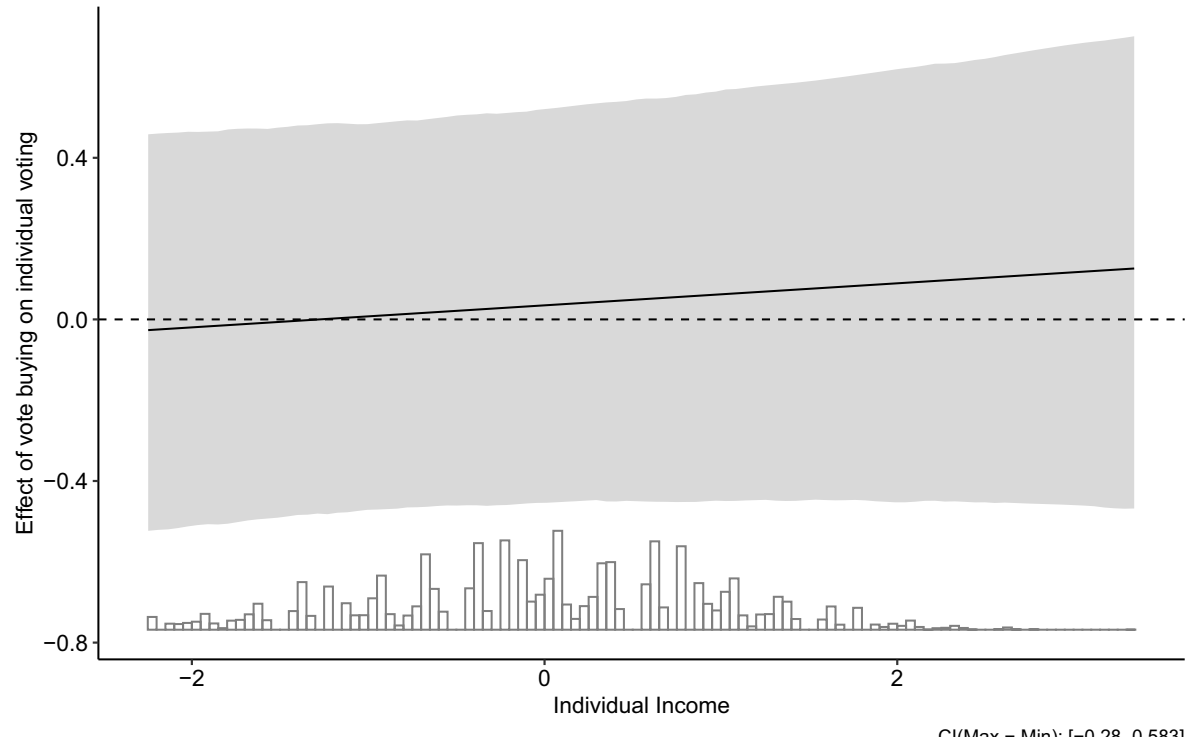

Fig. 3 Estimated Coefficients of Vote Buying by Individual Income (Based on Model 7 in Fig. 1. Conditional effects of individual income and vote buying. The lines represent the estimated change in the logged odds of the dependent. The shaded regions show adjusted $95 \%$ confidence intervals)

is relatively small and insignificant and does not meet the theoretical expectations. Fig. 3 shows the conditional effect of vote buying on different levels of income and also clearly indicates that the effect of vote buying is not conditional on the individual income level.

In summary, for my sample of authoritarian regimes, neither macro-level inequality nor individual income matters for the likelihood of voting. The models, therefore, provide no empirical support for the Relative Power and the Conflict Theories. However, the effect of individual income on voting is weak and substantially smaller than other individual predictors. Individual socioeconomic predictors such as individual income do not have not a great effect on the likelihood of voting. At the macro-level, fairness of elections, previous democratic experience of an authoritarian regimes and the social group base of the regime are the main drivers of individual voting probability. The results suggest a change of two standard deviations in the fairness of election results in a 0.97 increase in the logged odd ratio of voting. However, an estimated change from an -0.35 increase, a substantial negative effect, to an 2.36 increase, a substantial positive effect, indicates the uncertainty of the predicted estimate and indicates that fairness and clean elections may matter for voting likelihood. As my theoretical expectations suggest, when authoritarian elections are cleaner and free of fraud and violence, more individuals are likely to participate in them. In contrast, vote-buying does not matter for voting likelihood. 


\subsection{Civil society participation}

Fig. 4 reports the results of a series of multilevel models that estimate the effects on civil society participation of individuals in authoritarian regimes. Model 2 includes all individual-level variables. Individual income has a substantial positive effect on civil society participation, and confirms the assumption of the Relative Power and the Resource Theories that low individual income leads to less political participation. Furthermore, Fig. 4 shows that the uncertainty of the estimate is small. Further, the individual predictors show that higher education fosters participation, while age and unemployment have negative effects on the individual likelihood of civil society participation.

Model 3 adds the Gini index. Model 4 tests whether the effects hold when economic development, previous democratic experience, regime support groups and civil society repression on the country-year level are controlled for. Model 5 allows that the effect of individual income can vary in the effect size and direction between the country-years by including random slopes. The findings show that a change of one standard deviation below the mean to one standard deviation above the mean in the macro-level economic inequality results in 0.07 decrease in the logged odd ratio of civil society participation. ${ }^{17}$ However, an estimated change from a 0.66 decrease, a substantial negative effect, to a 0.51 increase, a substantial positive association, shows the uncertainty of the predicted estimate. However, the negative point estimate indicates that economic inequality leads to lower civil society participation. However, as indicated by Fig. 4 the effect direction is mixed among the models. Section C. 2 estimates the effect of disposable inequality on civil society participation, and shows that the results hold while using post-tax Gini measurements.

In contrast to the findings on voting likelihood, repression does not matter for civil society participation. Fig. 4 indicates that a change of one standard deviation below to one standard deviation above the mean in the repression of civil society organizations results in a non-substantial change in the logged odd ratio of civil society participation. However, an estimated change from a 0.32 decrease, a substantial negative effect, to a 0.87 increase, a substantial positive association, shows the uncertainty of the predicted estimate. ${ }^{18}$ This indicates that the level of civil society repression by authoritarian regimes is not the main factor driving the likelihood of individual participation in civil society. Therefore, my theoretical expectation in $\mathrm{H} 4$ does not hold for civil society participation. In addition, Fig. 4 shows that previous democratic experience as well as the regime support groups have a positive and significant effect on civil society participation in all models.

Fig. 5 plots the cross-level interaction of income and inequality and clearly indicates that with increasing individual income, inequality was estimated to decrease political participation of the lower-level income group and to increase the political participation of the higher-level income groups. However, the expected interaction effects range from small negative to strong positive associations at different income levels, thus indicating that the effect is highly uncertain. This finding is consistent

17 Based on Model 6.

18 Based on Model 6 in Fig. 4. 


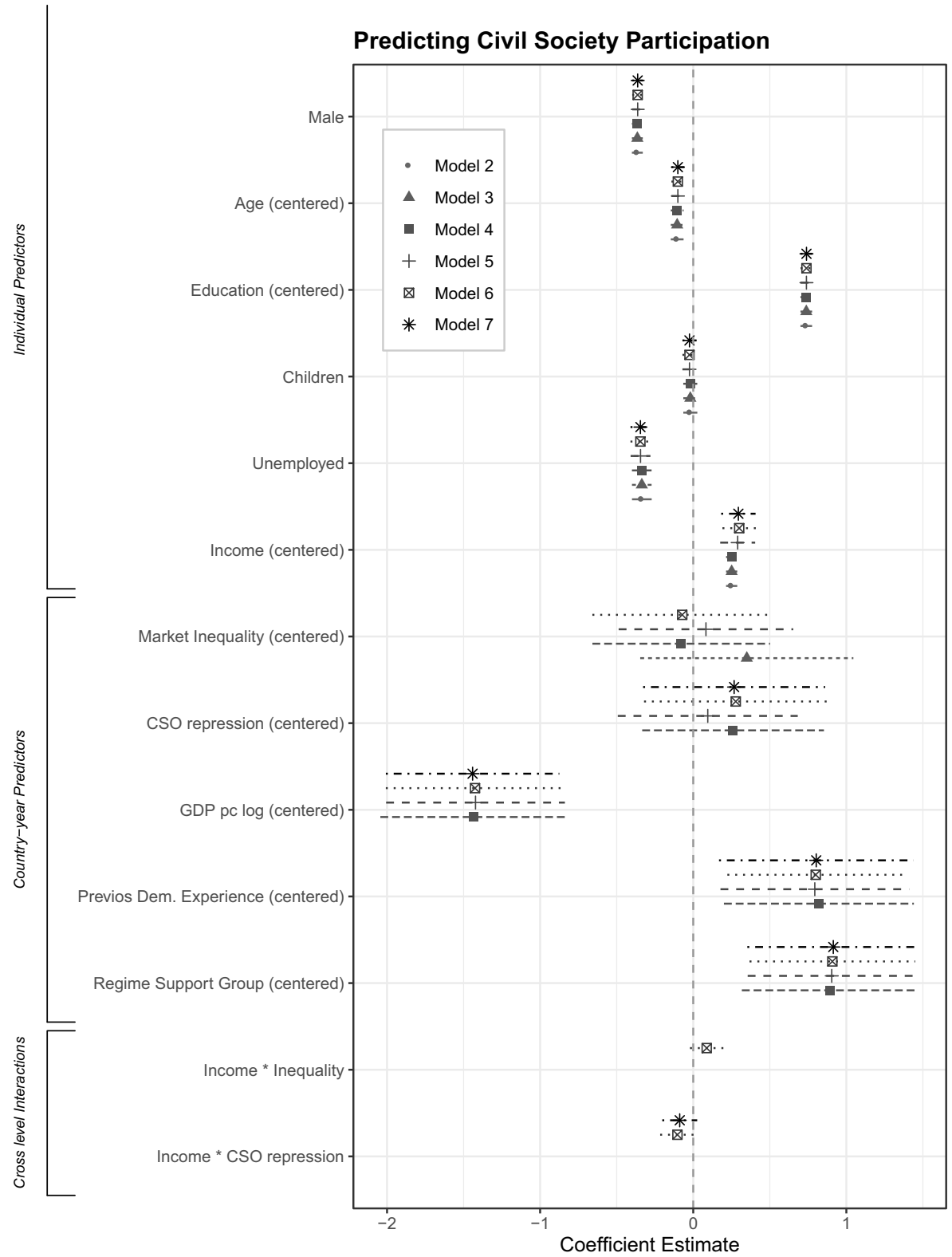

Fig. 4 Effects of Income, Inequality, and Repression on Civil Society Participation (The dots represent the estimated changes in the logged odds of civil society participation (dependent variable) occurring for a change of two standard deviations in the predictor variables. The whiskers show the $95 \%$ confidence intervals of these estimates) 


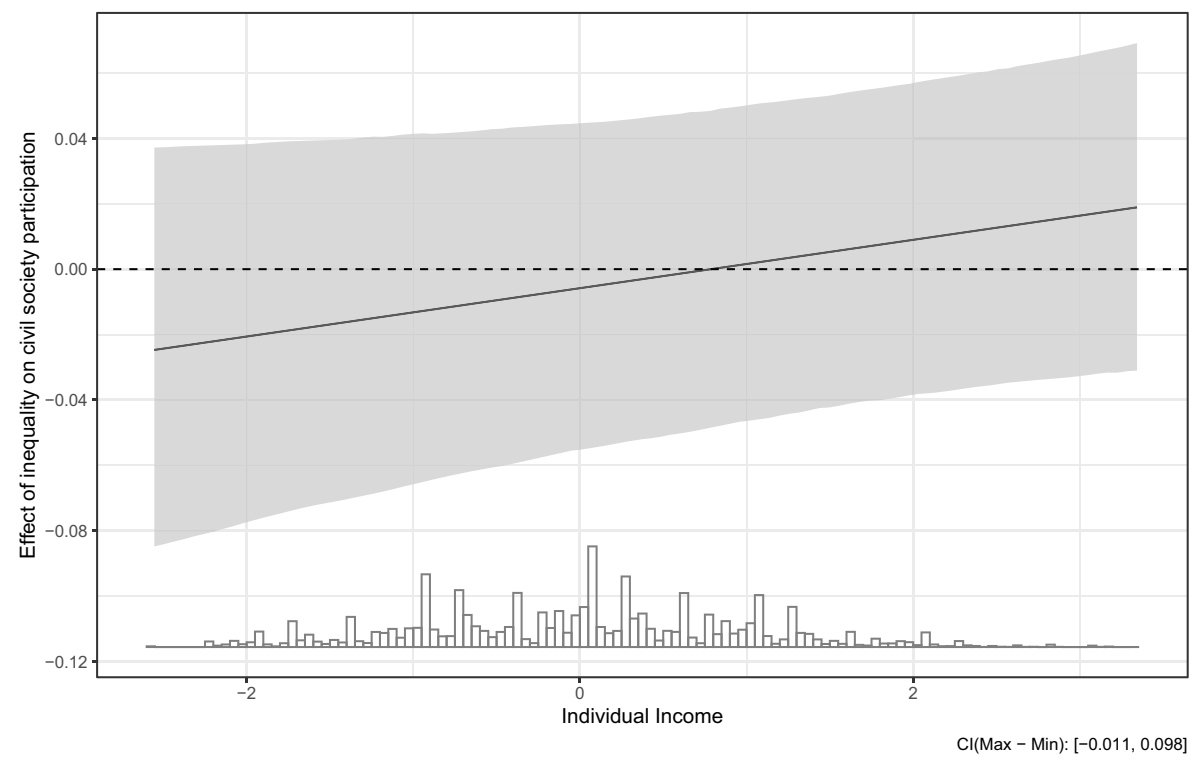

Fig. 5 Estimated Coefficients of Inequality by Individual Income on Civil Society Participation (Based on Model 6 in Fig. 4. Conditional effects of individual income and market inequality. The lines represent the estimated change in the logged odds of the dependent variable. The shaded regions show adjusted $95 \%$ confidence intervals)

with the Resource Theory and contradicts the Relative Power and the Conflict Theories. The Relative Power Theory assumes that the effect of income inequality and the interaction between income and inequality matter more than individual income. The Conflict Theory assumes that economic inequality increases political participation at all levels of income. In contrast, the findings support the Resource Theory, which maintains that the effect of individual income is greater than the product of inequality and the interaction.

Fig. 6 plots the estimated effect of the repression of CSO across income levels. This interaction indicates that the repression of civil society organizations was estimated to increase political participation in the lower-level income group and decrease political participation in the higher-level income groups. However, the expected interaction effects range from small negative to strong positive associations at different income levels, indicating the effect of repression of CSO on the participation likelihood is highly uncertain. Where there is a greater repression of civil society organizations, individuals with low income are more likely to participate in civil society, while individuals with higher income are less to do so. The finding clearly contradicts $\mathrm{H} 4$, and indicates that the repression of civil society organizations can affect the poor more than the rich.

To sum up the interaction effects, in authoritarian regimes the poor are less likely to participate in civil society when the macro-level inequality is high. Therefore, the models support the Resource Theory. In authoritarian regimes with high levels of repression of civil society organizations, the poor are more likely to participate in civil society than more affluent individuals. 


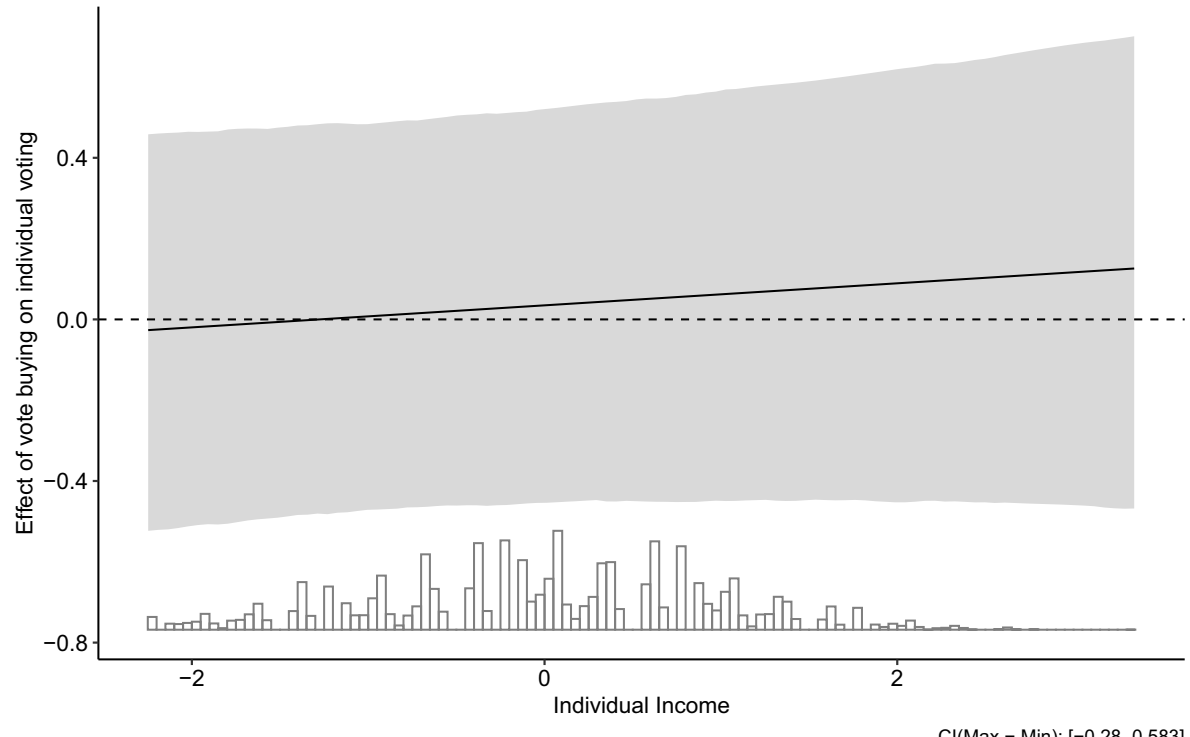

Fig. 6 Estimated Coefficients of Repression of Civil Society Organization by Individual Income on Civil Society Participation (Based on Model 7 in Fig. 4. Conditional effects of individual income and market inequality. The lines represent the estimated change in the logged odds of the dependent variable. The shaded regions show adjusted $95 \%$ confidence intervals)

\subsection{Robustness tests}

The results in the Supplementary Online Appendix show that the findings estimated by the main models are robust to additional tests. First, I tested to see if the findings remained stable, when I used income deciles. Sections D.1 and D.2 indicate that the effect and the strength of the association of individual income on electoral participation remain largely unchanged by using income deciles for measuring individual income. Sections E.1 and E.2 test the effect of income deciles for civil society participation predictions. The main results hold.

Second, the main analysis does not include different measurements of inequality for the main independent variable. Sections D.3 and E.3 test to see whether the results of the main models hold while using UNU-WIDER Gini coefficients to measure macro-level income inequality. The findings show that the results are robust to the use of these different Gini measures.

Third, Section D.4 controls for the effect of compulsory voting systems and shows that the main results hold. Section E. 4 and E.5 control for the construction of the dependent civil society participation variable. The modified variable excludes individual participation in political parties and party-based organizations. The main results hold.

Sections D.6 and E.6 use multiple imputation to address the problem of missing individual observations. The multiple imputed datasets cover 43,074 individuals in the Electoral Participation Dataset and 95,175 individuals for the Civil Society Participation dataset. Both sections show that the main results hold. 


\section{Conclusion and discussion}

This article argues that individual income and the level of repression determine the likelihood of political participation, while economic inequality has no substantial effect on the participation likelihood. The intuition underlying this expectation is that individuals misperceive the actual level of inequality (Ansell and Samuels 2011; Gimpelson and Treisman 2018; Mijs 2019).

The theoretical expectations were tested using three-level hierarchical models with World Value Survey Data and data from V-Dem and SWIID. This study found that economic inequality has a consistent non-significant effect on political participation, while the effect of income and repression vary across different types of political participation. By making four claims, this article has important implications for our understanding of authoritarian politics.

First, in accordance with Albertus and Menaldo (2018), Ansell and Samuels (2014), and Haggard and Kaufman (2016), this study weakens the assumption on the distributive nature of democratization. It shows that macro-level inequality does not increase political participation, both in elections and in civil society in nondemocratic regimes. Thus, one causal chain of the so-called distributive conflict models (e.g., Acemoglu and Robinson 2006; Boix 2003) is challenged by showing that economic inequality does not lead to increased participation of the population. However, this is only an indirect test of the assumption that economic inequality leads to anti-regime mobilization due to the definition of my dependent variable.

In addition, previous studies have shown that individuals misperceive the level of economic inequality (Ansell and Samuels 2011; Gimpelson and Treisman 2018; Lupu and Pontusson 2011; Mijs 2019). When perceived inequality correlates strongly "with demand for redistribution and reported conflict between rich and poor" (Gimpelson and Treisman 2018, p. 27), the actual level of economic inequality should be a poor predictor of redistributive preferences, and, if the distributive conflict models are right, of the likelihood of political participation of individuals. Therefore, it cannot be the main mechanism explaining political participation.

Second, this article presents evidence that economic inequality depresses political participation in terms of voting and has no substantial effect on civil society participation (cf. H2). However, in contrast to the assumption of the Relative Power Theory, which predicts a decrease in participation at higher levels of economic inequality, I find that the relationship holds only for highly institutionalized types of participation such as voting. Nevertheless, the uncertainty of this relationship is high, indicating that economic inequality can have positive effects in some cases.

Third, this article finds a gap between the positive effects of individual income on the likelihood of civil society participation and a small effect on the voting likelihood. Individual income is, therefore, not a good predictor for voting, but for civil society engagement (cf. H1). In contrast to the assumptions of the Relative Power and Resource Theories, individual income does not matter for highly formalized and rare types of political participation such as voting, but matters for types of participation that are based on engagement that is more frequent and not as much formal as voting. Fourth, my findings, pertaining to the effect of macro-level variables such as the level of repression or the fairness and freedom of elections, are consistent with 
the findings of studies on political participation in authoritarian regimes (Blaydes 2006; Frantz 2018; Miller 2017). This study shows that the perceptions of individuals of the risk to receive penalties matter for the likelihood of participation (cf. H4). However, the analysis also shows that more precise measurement methodology is required to capture relevant political phenomena, such as vote buying and inequality perceptions to reducing measurement biases by proxies.

One key implication of this study pertains to the theoretical arguments linking inequality and participation under authoritarianism. The scope of the presented theoretical models, the Resource Theory, the Conflict Theory, and the Relative Power Theory is to illuminate the effect of inequality under democratic rule. However, this study readapts these theories in the context of authoritarian regimes and finds mixed results. It is important to note that the inferences made from this study do not curtail the validity and explanatory power of those theories for democratic contexts. Moreover, the findings indicate that the theoretical assumptions are inconclusive and the development of an original theory of inequality and participation in autocracies is indicated. This study has made a first step towards theory development.

Finally, this study has important implications for future studies on participation in authoritarian regimes. Authoritarian regimes do not fear political participation in general, in fact they promote such participation. What they worry about is losing (competitive) elections. This study provides preliminary evidence that authoritarian regimes should not agonize about rising economic inequality as a driver of antiregime participation and mobilization. However, using World Value Survey data, this study cannot distinguish between pro- and anti-government voting and civil society participation. Nevertheless, this article demonstrates the need for individuallevel data on voting for pro- and anti-government parties in authoritarian regimes to test the micro-foundations of the redistributive nature of regime instability and democratization.

Acknowledgements I appreciate the constructive feedback I received from the anonymous reviewers and the editors. In addition, I thank Aurel Croissant, David Kuehn and the participants at the Annual Conference of the Section 'Political Economy' of the DVPW (2019) for helpful comments.

Funding Open Access funding enabled and organized by Projekt DEAL.

Open Access This article is licensed under a Creative Commons Attribution 4.0 International License, which permits use, sharing, adaptation, distribution and reproduction in any medium or format, as long as you give appropriate credit to the original author(s) and the source, provide a link to the Creative Commons licence, and indicate if changes were made. The images or other third party material in this article are included in the article's Creative Commons licence, unless indicated otherwise in a credit line to the material. If material is not included in the article's Creative Commons licence and your intended use is not permitted by statutory regulation or exceeds the permitted use, you will need to obtain permission directly from the copyright holder. To view a copy of this licence, visit http://creativecommons.org/licenses/by/4. $0 /$.

Conflict of interest L. Pelke declares that he has no competing interests. 


\section{References}

Acemoglu, Daron, and James A. Robinson. 2006. Economic origins of dictatorship and democracy. Cambridge: Cambridge University Press.

Acemoglu, Daron, Simon Johnson, James A. Robinson, and Pierre Yared. 2005. From education to democracy? American Economic Review 95:44-49. https://doi.org/10.1257/000282805774669916.

Albertus, Michael, and Victor Menaldo. 2018. Authoritarianism and the elite origins of democracy. Cambridge: Cambridge University Press.

Alesina, Alberto, and Eliana La Ferrara. 2000. Participation in Heterogeneous Communities*. Quarterly Journal of Economics 115:847-904. https://doi.org/10.1162/003355300554935.

Ansell, Ben, and David Samuels. 2011. Inequality and democratization: Individual-level evidence of preferences for redistribution under autocracy. In Annual Meeting of the American Political Science Association. https://papers.ssrn.com/sol3/papers.cfm?abstractid=1903333. Accessed 7 Oct 2020.

Ansell, Ben, and David Samuels. 2014. Inequality and democratization. An elite-competition approach. New York: Cambridge University Press.

Blaydes, Lisa. 2006. Who votes in authoritarian elections and why? Determinants of voter turnout in contemporary Egypt. In Annual Meeting of the American Political Science Association. http://citeseerx. ist.psu.edu/viewdoc/download?doi=10.1.1.457.5619\&rep=rep1\&type=pdf. Accessed 7 Oct 2020.

Boix, Carles. 2003. Democracy and redistribution. Cambridge studies in comparative politics. Cambridge: Cambridge University Press.

Brady Henry, E. 1998. Political participation. In Measures of political attitudes, ed. J.P. Robinson, P.R. Shaver, and L.S. Wrightsman, 737-801. San Diego: Academic Press.

Bratton, Michael. 2008. Poor people and democratic citizenship in Africa. In Poverty, participation, and democracy. A global perspective, ed. Anirudh Krishna, 28-64. Cambridge: Cambridge University Press.

Brownlee, Jason. 2011. Executive Elections in the Arab World: When and How Do They Matter?. Comparative Political Studies 44:807-828. https://doi.org/10.1177/0010414011402034.

Chang, Eric, and Miriam A. Golden. 2010. Sources of corruption in authoritarian regimes. Social Science Quarterly 91:1-20.

Chen, Jidong, and Yiqing Xu. 2017. Information manipulation and reform in authoritarian regimes. Political Science Research and Methods 5:163-178. https://doi.org/10.1017/psrm.2015.21.

Coppedge, Michael, John Gerring, Carl Henrik Knutsen, I. Lindberg Staffan, Jan Teorell, David Altman, Michael Bernhard, Steven M. Fish, Adam Glynn, Allen Hicken, Anna Lührmann, Kyle L. Marquardt, Kelly McMann, Pamela Paxton, Daniel Pemstein, Brigitte Seim, Rachel Sigman, Svend-Erik Skaaning, Jeffrey Steven Wilson Staton, et al. 2020a. V-Dem [country-year/country-date] Dataset v10. https://doi.org/10.23696/vdemds20.

Coppedge, Michael, John Gerring, Carl Henrik Knutsen, I. Lindberg Staffan, Jan Teorell, David Altman, Michael Bernhard, Steven M. Fish, Adam Glynn, Allen Hicken, Anna Lührmann, Kyle L. Marquardt, Kelly McMann, Pamela Paxton, Daniel Pemstein, Brigitte Seim, Rachel Sigman, Svend-Erik Skaaning, Jeffrey Agnes Cornell Staton, et al. 2020b. V-Dem Codebook v10. In Varieties of democracy ( $V$ Dem) project.

Croke, Kevin, Guy Grossman, Horacio A. Larreguy, and John Marshall. 2016. Deliberate disengagement: how education Can decrease political participation in electoral authoritarian regimes. American Political Science Review 110:579-600. https://doi.org/10.1017/S0003055416000253.

Davenport, Christian. 2007. State repression and political order. Annual Review of Political Science 10:1-23. https://doi.org/10.1146/annurev.polisci.10.101405.143216.

van Deth, Jan W. 2001. Studying Political Participation: Towards a Theory of Everything? In Joint Sessions of Workshops of the European Consortium for Political Research. Grenoble.

van Deth, Jan W. 2016. What is political participation? In Oxford research encyclopedia of politics, ed. William R. Thompson.

Elff, Martin, Jan Paul Heisig, Merlin Schaeffer, and Susumu Shikano. 2020. Multilevel analysis with few clusters: improving likelihood-based methods to provide unbiased estimates and accurate inference. British Journal of Political Science https://doi.org/10.1017/S0007123419000097.

Escribà-Folch, Abel. 2013. Repression, political threats, and survival under autocracy. International Political Science Review 34:543-560. https://doi.org/10.1177/0192512113488259.

Filetti, Andrea, and Jan Germen Janmaat. 2018. Income inequality and economic downturn in Europe: a multilevel analysis of their consequences for political participation. Acta Politica 53:327-347. https://doi.org/10.1057/s41269-017-0053-1. 
Frantz, Erica. 2018. Voter turnout and opposition performance in competitive authoritarian elections. Electoral Studies 54:218-225. https://doi.org/10.1016/j.electstud.2018.06.010.

Gandhi, Jennifer, and Ellen Lust-Okar. 2009. Elections under authoritarianism. Annual Review of Political Science 12:403-422. https://doi.org/10.1146/annurev.polisci.11.060106.095434.

Gandhi, Jennifer, and Elvin Ong. 2019. Committed or conditional democrats? Opposition dynamics in electoral autocracies. American Journal of Political Science 63:948-963. https://doi.org/10.1111/ajps. 12441.

Geddes, Barbara, Joseph Wright, and Erica Frantz. 2018. How dictatorships work: power, personalization, and collapse. Cambridge: Cambridge University Press.

Gerschewski, Johannes. 2013. The three pillars of stability: legitimation, repression, and co-optation in autocratic regimes. Democratization 20:13-38. https://doi.org/10.1080/13510347.2013.738860.

Gimpelson, Vladimir, and Daniel Treisman. 2018. Misperceiving inequality. Economics \& Politics 30:27-54. https://doi.org/10.1111/ecpo.12103.

Gonzalez-Ocantos, Ezequiel, Chad Kiewiet de Jonge, Carlos Meléndez, Javier Osorio, and David W. Nickerson. 2012. Vote Buying and Social Desirability Bias: Experimental Evidence from Nicaragua. American Journal of Political Science 56:202-217. https://doi.org/10.1111/j.1540-5907.2011.00540. $\mathrm{x}$.

Greene, Kenneth. 2009. Why dominant parties lose: Mexico's democratization in comparative perspective. Cambridge: Cambridge University Press.

Guriev, Sergei, and Daniel Treisman. 2015. How modern dictators survive: an informational theory of the new authoritarianism. NBER Working paper series. https://doi.org/10.3386/w21136.

Hadenius, Axel, and Jan Teorell. 2007. Pathways from authoritarianism. Journal of Democracy 18:143-157.

Haggard, Stephan, and Robert R. Kaufman. 2016. Dictators and democrats: masses, elites, and regime change. Princeton/Oxford: Princeton University Press.

Haggard, Stephan, Robert R. Kaufman, and James D. Long. 2013. Income, occupation, and preferences for redistribution in the developing world. Studies in Comparative International Development 48:113-140. https://doi.org/10.1007/s12116-013-9129-8.

He, B. 2007. Rural democracy in China: the role of village elections. New York: Palgrave Macmillan.

Hicken, Allen, Stephen Leider, Nico Ravanilla, and Dean Yang. 2015. Measuring vote-selling: field evidence from the Philippines. The American Economic Review 105:352-356.

Karakoc, Ekrem. 2013. Economic inequality and its asymmetric effect on civic engagement: evidence from post-communist countries. European Political Science Review 5:197-223. https://doi.org/10. 1017/S1755773912000100.

Knutsen, Carl Henrik, Håvard Mokleiv Nygård, and Tore Wig. 2017. Autocratic elections: stabilizing tool or force for change? World Politics 69:98-143. https://doi.org/10.1017/S0043887116000149.

Krishna, Anirudh. 2008. Do poor people care less for democracy? testing individual-level assumptions with individual-level data from India. In Poverty, participation and democracy, ed. Anirudh Krishna, 65-93. Cambridge: Cambridge University Press.

Lancee, Bram, and Herman G. Van de Werfhorst. 2012. Income inequality and participation: a comparison of 24 European countries. Social Science Research 41:1166-1178. https://doi.org/10.1016/j. ssresearch.2012.04.005.

Letsa, Natalie Wenzell. 2020. Expressive voting in autocracies: a theory of non-economic participation with evidence from Cameroon. Perspectives on Politics 18:439-453. https://doi.org/10.1017/ S1537592719001002.

Levitsky, Steven and Lucan A. Way. 2010. Competitive authoritarianism: hybrid regimes after the cold war. New York: Cambridge University Press.

Lührmann, Anna, Marcus Tannenberg, and I. Lindberg Staffan. 2018. Regimes of the world (RoW): opening new avenues for the comparative study of political regimes. Politics and Governance 6:60-77. https://doi.org/10.17645/pag.v6i1.1214.

Lupu, Noam, and Jonas Pontusson. 2011. The structure of inequality and the politics of redistribution. American Political Science Review 105:316-336. https://doi.org/10.1017/S0003055411000128.

Magaloni, Beatriz. 2006. Voting for autocracy: hegemonic party survival and its demise in Mexico. Cambridge: Cambridge University Press.

Mares, Isabela, Aurelian Muntean, and Tsveta Petrova. 2017. Pressure, favours, and vote-buying: experimental evidence from Romania and Bulgaria. Europe-Asia Studies 69:940-960. https://doi.org/10. 1080/09668136.2017.1364351.

Mauk, Marlene. 2020. Citizen support for democratic and autocratic regimes. Comparative politics. Oxford: Oxford University Press. 
Meltzer, Allan H., and Scott F. Richard. 1981. A rational theory of the size of government. Journal of Political Economy 89:914-927. https://doi.org/10.1086/261013.

Mijs, Jonathan J.B. 2019. The paradox of inequality: income inequality and belief in meritocracy go hand in hand. Socio-Economic Review. https://doi.org/10.1093/ser/mwy051.

Miller, Steven V. 2017. Economic threats or societal turmoil? Understanding preferences for authoritarian political systems. Political Behavior 39:457-478. https://doi.org/10.1007/s11109-016-9363-7.

Morgenbesser, Lee, and Thomas B. Pepinsky. 2019. Elections as causes of democratization: southeast asia in comparative perspective. Comparative Political Studies 52:3-35. https://doi.org/10.1177/ 0010414018758763.

Nichter, Simeon. 2008. Vote buying or turnout buying? Machine politics and the secret ballot. American Political Science Review 102:19-31. https://doi.org/10.1017/S0003055408080106.

Paglayan, Agustina S. 2020. The non-democratic roots of mass education: evidence from 200 years. American Political Science Review. Online first. https://doi.org/10.1017/S0003055420000647.

Persson, Mikael. 2015. Education and political participation. British Journal of Political Science 45:689-703. https://doi.org/10.1017/S0007123413000409.

Ritter, Michael, and Frederick Solt. 2019. Economic inequality and campaign participation. Social Science Quarterly 100:678-688. https://doi.org/10.1111/ssqu.12605.

Robinson, Darrel, and Marcus Tannenberg. 2019. Self-censorship of regime support in authoritarian states: evidence from list experiments in China. Research \& Politics https://doi.org/10.1177/ 2053168019856449.

Schedler, Andreas. 2013. The politics of uncertainty: sustaining and subverting electoral authoritarianism. Oxford: Oxford University Press.

Schmidt-Catran, Alexander W. 2016. Economic inequality and public demand for redistribution: combining cross-sectional and longitudinal evidence. Socio-Economic Review 14:119-140. https://doi.org/ 10.1093/ser/mwu030.

Solt, Frederick. 2008. Economic inequality and democratic political engagement. American Journal of Political Science 52:48-60.

Solt, Frederick. 2010. Does economic inequality depress electoral participation? Testing the Schattschneider hypothesis. Political Behavior 32:285-301. https://doi.org/10.1007/s11109-010-9106-0.

Solt, Frederick. 2020. Measuring income inequality across countries and over time: the standardized world income inequality database. Social Science Quarterly 101:1183-1199. https://doi.org/10.1111/ssqu. 12795.

Solt, Frederick, Yue Hu, Kevan Hudson, Jungmin Song, and Dong Yu. 2016. Economic inequality and belief in meritocracy in the United States. Research \& Politics https://doi.org/10.1177/ 2053168016672101.

Solt, Frederick, Yue Hu, Kevan Hudson, Jungmin Song, and Dong Yu. 2017. Economic inequality and class consciousness. The Journal of Politics 79:1079-1083. https://doi.org/10.1086/690971.

Solt, Frederick, and Yue Hu. 2015. Dotwhisker: dot-and-whisker plots of regression results. https://cran.rproject.org/web/packages/dotwhisker/vignettes/dotwhisker-vignette.html. Accessed 7 Oct 2020.

Tannenberg, Marcus. 2017. The autocratic trust bias: politically sensitive survey items and self-censorship. V-Dem Working Paper 49. https://www.v-dem.net/media/filer_public/41/87/41873911-3093-4a08a2b9-f80cb24d3975/v-dem_working_paper_2017_49.pdf. Accessed 7 Oct 2020.

Uslaner, Eric M., and Mitchell Brown. 2005. Inequality, trust, and civic engagement. American Politics Research 33:868-894. https://doi.org/10.1177/1532673X04271903.

Verba, Sidney, Kay Lehman Schlozman, and Henry Brady. 1995. Voice and equality: civic voluntarism in American politics. Cambridge: Harvard University Press.

World Values Survey. 2016. Longitudinal dataset: country-pooled datafile version. Madrid: JD Systems Institute.

Wright, Joseph, and Abel Escribà-Folch. 2012. Authoritarian institutions and regime survival: transitions to democracy and subsequent autocracy. British Journal of Political Science 42:283-309. https://doi. org/10.1017/S0007123411000317.

Yom, Sean. 2015. From Methodology to Practice: Inductive Iteration in Comparative Research. Comparative Political Studies 48:616-644. https://doi.org/10.1177/0010414014554685. 